\title{
Future Domestic Water Demand for Jeddah City
}

\author{
Ahmed Samy Kamis \\ Department of Hydrology and Water Resources Management \\ Faculty of Meteorology, Environment and Arid Land Agriculture \\ King Abdulaziz University, Jeddah, Saudi Arabia
}

\begin{abstract}
The paper discusses the present and future (1431-1460 A.H.) water demand and water resources for the domestic use in Jeddah city. Projection of both water demand driven by population as well as water resources are illustrated. Three scenarios are presented representing high, moderate and low cases for the population. Under each case, the level of water shortage problem is addressed and it is shown that without water conservation Jeddah city will face significant water shortage.
\end{abstract}

Keywords: Jeddah city, domestic water, water shortage, water shortage problem, water resources.

\section{Introduction}

The National Development Plans for the Kingdom of Saudi Arabia entail the provision for water of adequate quality to meet public health standards and quantity to provide for the total requirements of the population. Previous surveys (Abu-Rizaiza et al., 1988) have shown that the Jeddah-Makkah-Taif area to be the most water deficit area in the Western Region. Jeddah city is one of the seven large cities in the Kingdom. It has the largest airport and seaport in the Kingdom as it is the major and pivot point en route to the Holy Mosque in Makkah. The population of Jeddah has increased from 916000 capita in 1980 (Allehaibi, 1996) to 2801481 in 2004 (Central Department for Statistics and Information, 2008). In the same period the water supply from Jeddah desalination plant increased from 56.688 million $\mathrm{m}^{3}$ per year to 142.78 million $\mathrm{m}^{3}$ per year. Despite the significant increase in the capacity of the 
desalination plant, the demand increased substantially due to the large increase of population.

The objectives of this paper are to present the current and future (1431-1460 A.H.) water resources and demands for the domestic water supply. The current water resource is Jeddah desalination plant which will be used to forecast the future water supply as the present rate of development will be retained. The current water demand is decomposed into the population and the demand rate. Based on the current population, three population projection are investigated, namely, low, moderate and high cases. The current demand rate will be retained and then it will be used as one measure for water conservation in order to bring the supply and demand in balance.

\section{Water Supply}

Domestic water supply to Jeddah city is mainly from Jeddah desalination plant. Table 1 shows the amounts of desalinated water produced by this plant from 1405 A.H. up to 1416 A.H. (Ministry of Planning, 1995). The rest of the data up to 1429 A.H. was obtained from annual reports of the Saline Water Conversion Cooperation (2004-2009).

Table 1. Water production in thousand $\mathrm{m}^{3}$ for Jeddah desalination plant.

\begin{tabular}{|c|c|c|c|c|c|}
\hline Year & Production & Year & Production & Year & Production \\
\hline 1405 & 111568 & 1414 & 143474 & 1423 & 140777 \\
\hline 1406 & 109347 & 1415 & 154335 & 1424 & 146234 \\
\hline 1407 & 107760 & 1416 & 150049 & 1425 & 136377 \\
\hline 1408 & 109380 & 1417 & 149731 & 1426 & 140352 \\
\hline 1409 & 116837 & 1418 & 150603 & 1427 & 148896 \\
\hline 1410 & 133056 & 1419 & 152574 & 1428 & 151231 \\
\hline 1411 & 131011 & 1420 & 154544 & 1429 & 147715 \\
\hline 1412 & 134861 & 1421 & 150503 & 1430 & 145648 \\
\hline 1413 & 134818 & 1422 & 142110 & 1431 & 122273 \\
\hline
\end{tabular}

Projected water production is predicted based on extrapolation of the present production data using linear function as it gives the best fit. Figure.1 illustrates the present and future projection of the desalinated water. 


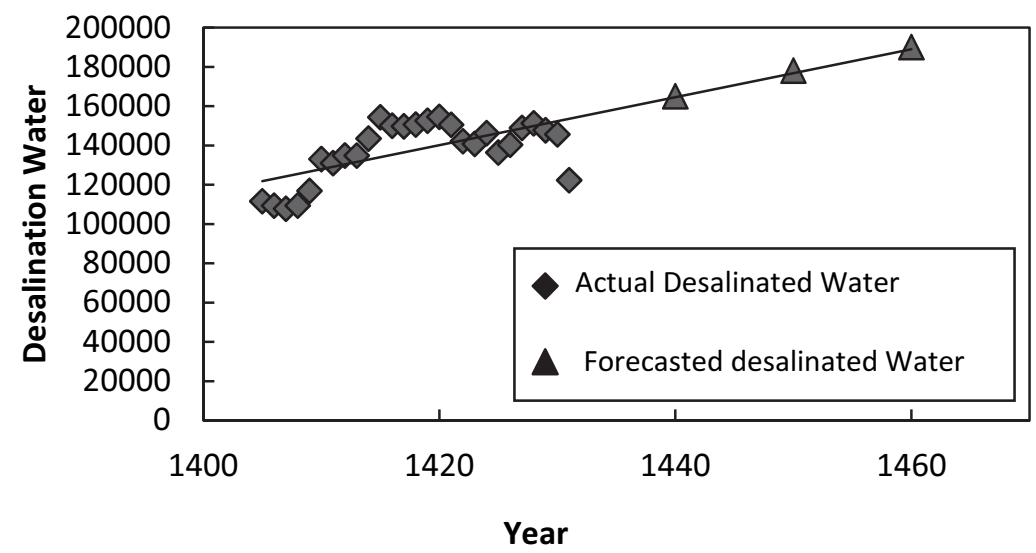

Fig. 1. Actual and forecasted desalinated water in $000^{\prime} \mathrm{m}^{3}$.

Table (1) shows a steady rate of increase of water production. Starting from 1423, Al-Shoaibah desalination plant started diverting about 85 million $\mathrm{m}^{3}$ of its production of water to Jeddah to improve the supply and combat the shortage.

\section{Water Demand}

Water demands are classified into two categories, municipal and industrial. However, as the industrial demands in Jeddah represent about $4 \%$ of the total demands, so it will be incorporated within the municipal water demands (Ministry of Economy and Planning, 2008). Municipal water demands can be decomposed into population and rate of water consumption. Population of Jeddah city obtained from data collected from its different municipalities for the years 1980, 1985 and 1990 (Allehaibi, 1996) were found 916000, 1076662 and 1475990 capita respectively. It is to be noticed that these figures include the non-Saudi citizens. Further census at 1413, 1425 and 1431 were conducted. Future estimates of population can be obtained using various methods (Steel and McGhee, 1985). However, due to the lack of lengthy data to conduct a proper population forecast, three simple methods have been used; one that gives high rate of growth, one that gives low rate of growth and an average between the two results to represent a moderate case. The first method that gives a high rate of growth is the Geometrical Progression Method. Under this method, it is assumed that the population growth rate is proportional to the population, i.e. 
$\frac{d Y}{d t}=K_{g} Y$

Where $\mathrm{dY} / \mathrm{dt}$ is the change in population, $\mathrm{Kg}$ is the geometric rate of increase and $\mathrm{Y}$ is the population. Integrating Eq. 1 and setting the limits yields;

$K_{g}=\frac{\ln Y_{2}-\ln Y_{1}}{t_{2}-t_{1}}$

Where $Y_{1}$ and $Y_{2}$ are two consecutive censuses and $t_{1}$ and $t_{2}$ are the years of these two censuses. Thus the population estimate is given by:

$\ln Y_{2}=\ln Y_{1}+K_{g}\left(t_{2}-t_{1}\right)$

The second low growth rate method is the Arithmetic Method which assumes that the rate of population change has been and will remain constant,

$\frac{d Y}{d t}=K_{u}$

Where $K_{u}$ is the uniform growth rate. By integrating Eq. 4 and setting the limits, then the population estimate can be written as,

$Y_{2}=Y_{1}+K_{u}\left(t_{2}-t_{1}\right)$

Finally, the population estimates by the two previous methods along with the average values are given in Table 2 and are shown in Fig. 2.

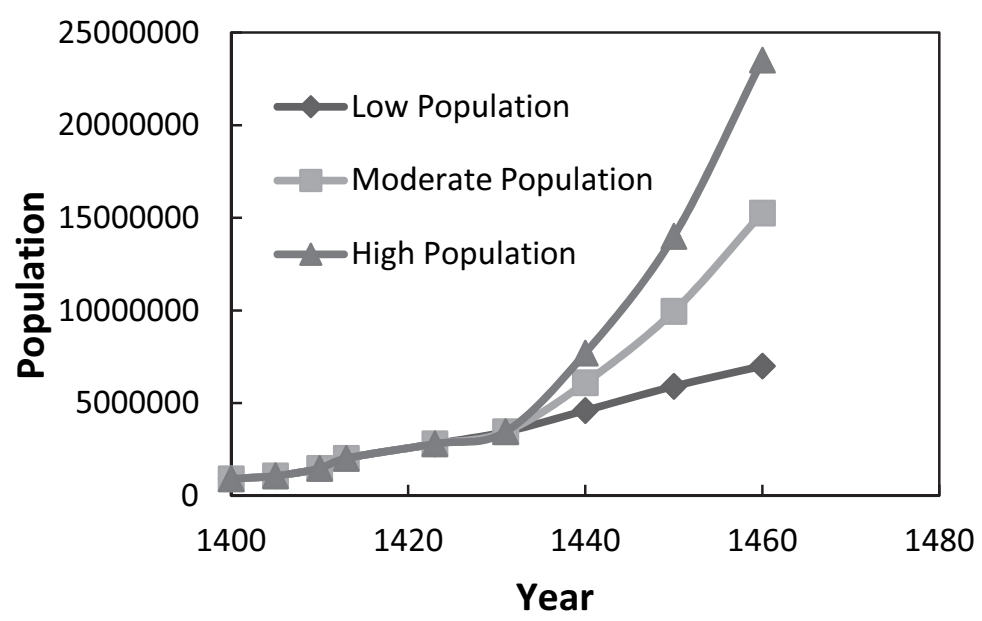

Fig. 2. Actual and forecasted population of Jeddah City. 
Table 2. Actual and forecasted future population (Capita) of Jeddah City.

\begin{tabular}{|c|c|c|c|}
\hline Year & Low Population & Moderate Population & High Population \\
\hline 1400 & 916000 & 916000 & 916000 \\
\hline 1405 & 1076662 & 1076662 & 1076662 \\
\hline 1410 & 1475990 & 1475990 & 1475990 \\
\hline 1413 & 2021095 & 2021095 & 2021095 \\
\hline 1423 & 2801481 & 2801481 & 2801481 \\
\hline 1431 & 3456259 & 3456259 & 3456259 \\
\hline 1440 & 4381369 & 5958699 & 7536028 \\
\hline 1450 & 5310714 & 9399232 & 13487750 \\
\hline 1460 & 6240060 & 15190008 & 24139956 \\
\hline
\end{tabular}

Water consumption rate is not known as a figure for Jeddah city, however, it can roughly be estimated based on the population and the actual domestic water consumed (Statistics Yearbook, 1995, 2008). The values for years 1413 and 1423 were shown since actual population census were known. The latest Statistics Book 2009 did not show consumption for year 1431. Table 3 shows the estimated water consumption rate. It can be seen that the rate increased substantially in 1405 then it decreased in 1410 . A rate of $250 \mathrm{lit} / \mathrm{cap} /$ day will be assumed based on engineering judgment.

Table 3. Consumption rate (lit/cap/day).

\begin{tabular}{|c|c|c|c|}
\hline Year & Population & Water Consumed $\left(\mathrm{m}^{3}\right)$ & $\begin{array}{c}\text { Consumption rate } \\
\text { (lit/capita/day) }\end{array}$ \\
\hline 1400 & 916000 & 68086924 & 204 \\
\hline 1405 & 1076662 & 115792000 & 295 \\
\hline 1410 & 1475990 & 134309000 & 249 \\
\hline 1413 & 2021095 & 141330000 & 192 \\
\hline 1423 & 2801481 & 237127000 & 232 \\
\hline
\end{tabular}

\section{Results, Discussion and Analysis}

The results are presented as a comparison between the available water resource and the domestic water use. Figures 3 through 8 illustrate the output resulting from the three different cases high, moderate and low of population growth.

\section{i) Low Case}

As shown in Fig. 3, the available water will satisfy the water demand up to year 1435. It is to be noticed that the sudden rise in the water resources at year 1423 is due to the introduction of the new source from Al-Shoaibah desalination plant. After that year, water shortage is 
expected. Therefore, conservation measure must be implemented to alleviate the problem. If the rate of consumption is reduced to 200 lit/cap/day, which is a reasonable figure that can be attained, the water will cover the demands to the end of the simulation period, year 1460 as shown in Fig. 4.

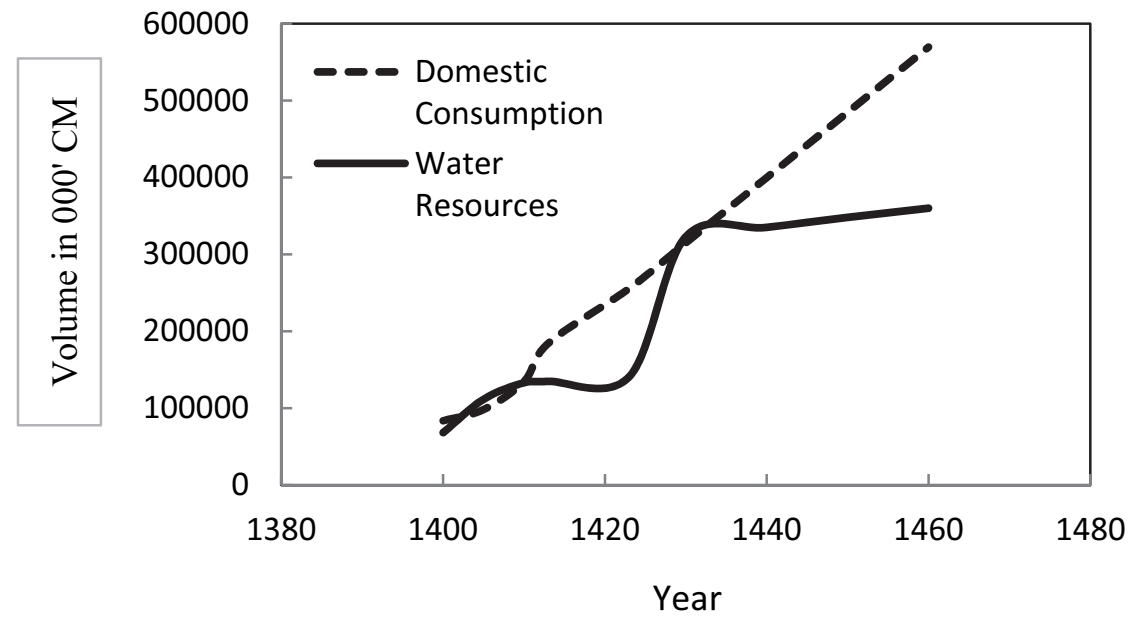

Fig. 3. High case (250 1/cap/day).

\section{ii) Moderate Case}

Figure 5 shows that the water shortage problem will be present at year 1432. By reducing the rate of consumption to $200 \mathrm{lit} / \mathrm{cap} /$ day, water will cover the demand till year 1442 as shown in Fig. 6.

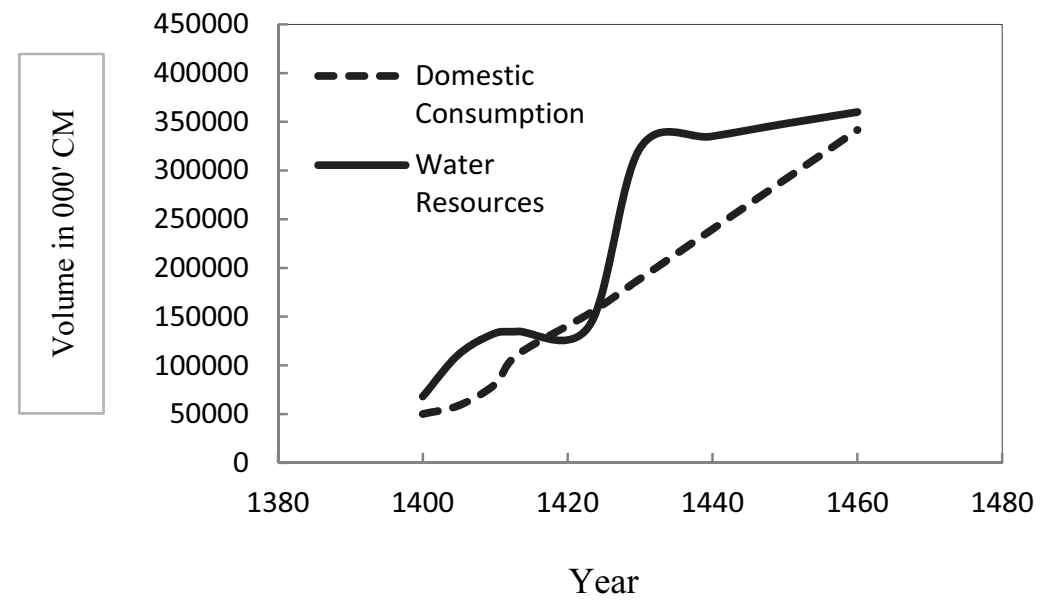

Fig. 4. High Case (200 1/cap/day). 


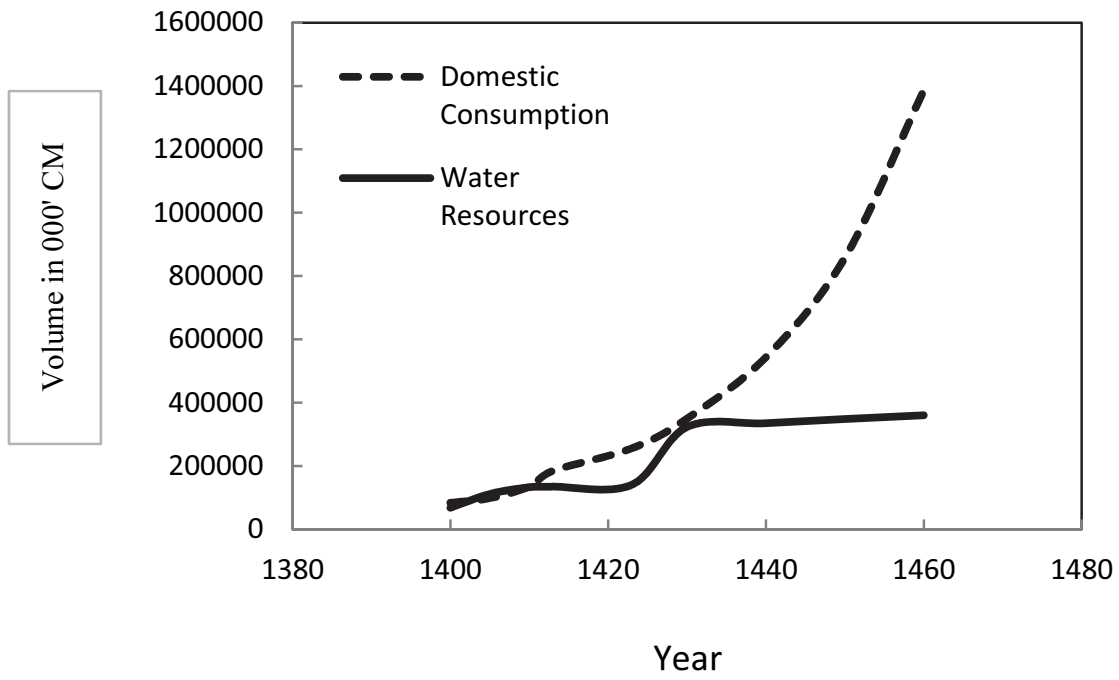

Fig. 5. Moderate case (250 1/cap/day).
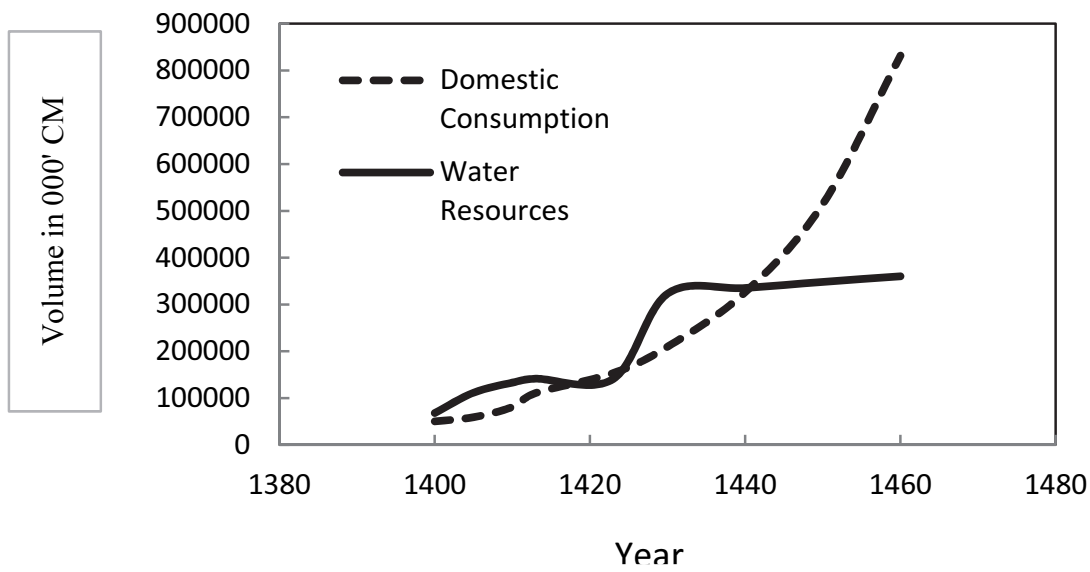

Fig. 6. Moderate case (200 1/cap/day).

\section{iii)High Case}

Figure 7 illustrates that water shortage already occurs in this case. While, if the rate of consumption is reduced to $200 \mathrm{lit} / \mathrm{cap} /$ day shortage will be delayed up to year 1438 as shown in Fig. 8 .

The results point out that water shortage is pound to occur in future even under the moderate case. Therefore, now is the time for earlier planning as the present rate of development of desalination water production is not coping with the rate of increase of population. In fact it 
is fortunate that a national campaign is launched to conserve water and it is hoped that this will lead to the reduction of the rate of water consumption.

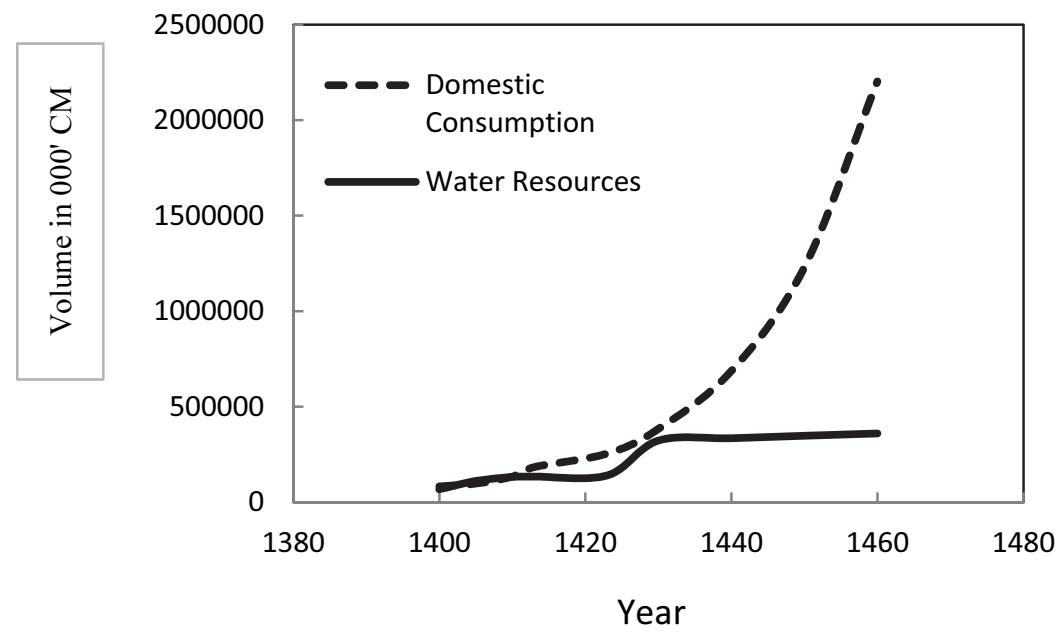

Fig. 7. Low case (250 1/cap/day).

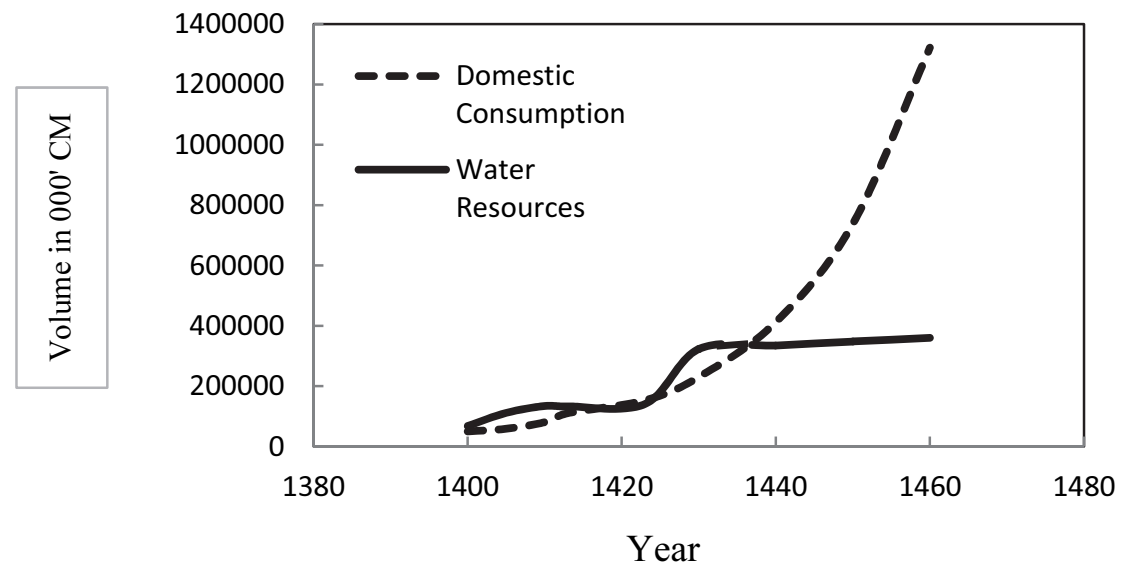

Fig. 8. Low case (200 1/cap/day).

\section{Conclusion}

In this paper, it is demonstrated that the current development plan for desalination water for Jeddah city will not cope with the population 
increase in the near future. Three cases; high, moderate and low rate for Jeddah population increase are explored. Even under the moderate case it was shown that the current plan can not cover the domestic requirement if the current rate of water consumption is remained unchanged. However, if this rate is reduced to $200 \mathrm{lit} / \mathrm{cap} /$ day, the current plan will satisfy the demand up to year $1460 \mathrm{AH}$ only under the low case. If the current conservation plan is successfully carried out, the current development plan will satisfy the demand up to year $1442 \mathrm{AH}$ under the moderate case. Therefore, it is suggested that an increase in the desalination production is needed to satisfy the demands up to year 1460 AH. This is based on the successful execution of the conservation measures being undertaken in the meantime.

\section{References}

Abu-Rizaiza, O.S., Allam, M.N., Basmaci, Y., Khan, M.Z.A., Bokhary, A.Y. and Abudurrazzak, M.J. (1988) Water Resources Potential, Allocation and reuse in Western Region. Final Report, AR - 6-075, King Abdulaziz City for science and Technology, Saudi Arabia, pp. 1.1-15.12.

Abu-Rizaiza, O.S., Allam, M.N. and Abdurrazzak, M.J. (1994) Water Supply and Demand Modeling for the Jeddah-Makkah-Taif area, Saudi Arabia: Present and Future Water Balance, 1. KA U: Meteorology. Environment and Arid Land Agriculture. 5: 119-133.

Allehaibi, A.H. (1996) Conservation of Domestic Water Use for Jeddah City by Using Simulation Model. M.SC. Thesis, Hydrorogy and Water Resources Management, Faculty of Meteorology, Environment and Arid Land Agriculture, King Abdulaziz University.

Central Department for Statistics and Information (2010), Census 1424 AH, and Census 1431 $A H$, http://www.cdsi.gov.sa/showproductstandard.aspx?lid=26\&pid=1651.

Ministry of Agriculture and Water (1417), Holy Makkah Region Water Project, Quarterly Reports Nos. 193,194,195 and 196.

Ministry of Agriculture and Water (1418), Holy Makkah Region Water Project, Quarterly Reports Nos. 197,198,199 and 200.

Ministry of Planning (1995) Statistical Year Book, Riyadh, Saudi Arabia, p. 291.

Ministry of Planning (2008) Statistical Year Book, Riyadh, Saudi Arabia, p. 8-16.

Ministry of Planning (2009) Statistical Year Book, Riyadh, Saudi Arabia, p. 8-16.

Saline Water Conversion Cooperation (2009), Annual Report 1430/1431, http://www.swcc.gov.sa/default.asp?pid=129

Steel, E. W. and McGhee, T.J. (1985) Water Supply and Sewerage. McGraw-Hill Co. 


\title{
الاحتياجات المستقبلية لمياه الثرب لمدينة جدة
}

\author{
أحمد سامي أحمد الزاهر قميص \\ قسم علوم و إدارة موارد المياه، كلية الأرصاد والبيئة وزراعة المناطق الجافة \\ جامعة الملك عبدالعزبز، جدة - المملكة العربية السعودية

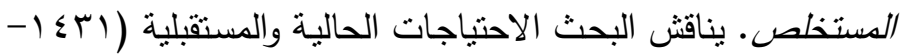

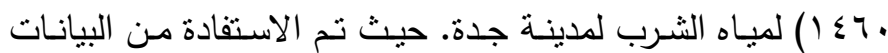 \\ السـابقة في توقـع الزيـادة السكانية وتطسور مصـادر الميـاه للمدينـة. \\ وبالنسبة للمستقبل فقد تم عرض ثلاثة حالات تمثل الزيادة السكانية

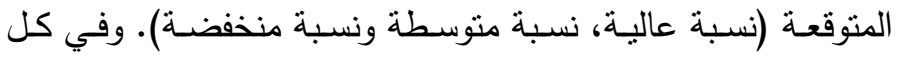

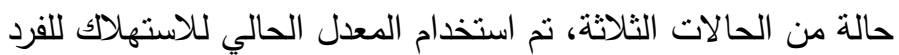

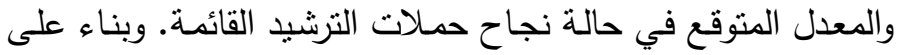 \\ هذه التوقعات تم تحديد مقدار النقص في المياه المتوقع واستخلاص

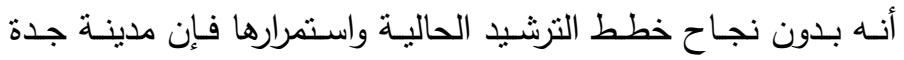 \\ ستعاني من نقص كبير في احتياجات مياه الثرب في المستقبل. \\ الكلمات الدالة: مدينة جدة، مياه الثرب، نقص المياه، مشكلة تخزين

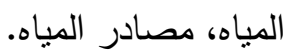

